\title{
RFLP readout introduces a type I error in meta-analysis of IL-6
}

\author{
Philipp G. Sand
}

Received: 1 June 2013/Accepted: 17 July 2013/Published online: 31 July 2013

(C) Springer-Verlag Berlin Heidelberg 2013

Dear Sirs,

I read with interest the recent meta-analysis of $I L-6$ effects in Alzheimer's disease [1]. Based on a set of 18 casecontrol investigations, the authors conclude to a protective effect of the "C" allele at $I L-6(-174 \mathrm{G} / \mathrm{C})$ under a recessive model in Alzheimer's disease. The majority of the previous association studies employed restriction fragment length polymorphism (RFLP) assays. However, pooling of earlier results was performed without correcting for RFLP readout, inflating overall effects. Of the 18 studies presented in Table 1 [1], only 14 provided adequate information for unambiguously defining the protective and at-risk alleles. Three of these [2-4] mistook the RFLP pattern of the "G" allele for that of the "C" allele on the transcribed DNA strand, as can easily be verified from the original protocol [2]. Dai et al. have now carried over these errors in their analysis and, consequently, have muddled IL-6 genotypes.

When non-informative studies that failed to specify DNA strand are excluded, and RFLP readout is corrected for in the other 14 studies, the total effects become nonsignificant both for model 1 (CC vs. GC + GG, see Fig. 1 in [1]) at $p=0.089(\mathrm{OR}=0.75,95 \% \mathrm{CI}=0.54-1.04)$ and for model 4 (CC vs. GC, see Fig. 4 in [1]) at $p=0.347$ $(\mathrm{OR}=0.87,95 \% \mathrm{CI}=0.65-1.16)$. Moreover, given the number of models examined, the adjusted impact of $(-174 \mathrm{G} / \mathrm{C})$ on the phenotype under study is even less meaningful ( $p_{\text {corrected }}>0.35$ ). On the whole, the evidence available to Dai et al. at the time of submission (total $N_{\text {corrected }}=6,000$ ) did not support a protective role of this IL-6 polymorphism in Alzheimer's disease.

Conflicts of interest There is no conflict of interest.

\section{References}

1. Dai L, Liu D, Guo H, Wang Y, Bai Y (2012) Association between polymorphism in the promoter region of Interleukin $6(-174 \mathrm{G} / \mathrm{C})$ and risk of Alzheimer's disease: a meta-analysis. J Neurol 259:414-419

2. Bagli M, Papassotiropoulos A, Knapp M, Jessen F, Luise Rao M, Maier W, Heun R (2000) Association between an interleukin-6 promoter and 3' flanking region haplotype and reduced Alzheimer's disease risk in a German population. Neurosci Lett 283: 109-112

3. Shibata N, Ohnuma T, Takahashi T, Baba H, Ishizuka T, Ohtsuka M, Ueki A, Nagao M, Arai H (2002) Effect of IL-6 polymorphism on risk of Alzheimer disease: genotype-phenotype association study in Japanese cases. Am J Med Genet 114:436-439

4. Faltraco F, Bürger K, Zill P, Teipel SJ, Möller HJ, Hampel H, Bondy B, Ackenheil M (2003) Interleukin-6-174 G/C promoter gene polymorphism $\mathrm{C}$ allele reduces Alzheimer's disease risk. J Am Geriatr Soc 51:578-579
P. G. Sand ( $\square)$

Department of Psychiatry, University of Regensburg,

Universitaetsstrasse 84, 93053 Regensburg, Germany

e-mail: philipp.sand@ukr.de 